RESEARCH REPORT

\title{
Political coalitions and working women: how the tobacco industry built a relationship with the Coalition of Labor Union Women
}

\author{
Edith D Balbach, Abby Herzberg, Elizabeth M Barbeau
}

J Epidemiol Community Health 2006;60(Suppl II):ii27-ii32. doi: 10.1136/jech.2006.046276

See end of article for authors' affiliations

.........................

Correspondence to: Professor E D Balbach, 112 Packard Avenue, Medford, MA 02155

USA; edith.balbach@tufts. edu

Accepted for publication 20 June 2006

\begin{abstract}
Objectives: To assess how the tobacco industry established a political relationship with the Coalition of Labor Union Women (CLUW) and to learn from this example how tobacco control advocates can work more effectively with organisations with which working class women are affiliated.

Methods: The study reviewed tobacco industry documents to determine Tobacco Institute strategy, using the CLUW News and other published material to corroborate our findings.

Results: The Tobacco Institute was effective at framing excise tax and smokefree worksite issues in a way that facilitated CLUW's support of industry positions on these issues. The Tobacco Institute was also willing to reciprocate by providing financial and other kinds of support to CLUW.

Conclusions: While tobacco control missed an opportunity to partner with CLUW on smokefree worksites and excise taxes in the 1980s and 1990s, tobacco control can also use issue framing and reciprocity to form coalitions with organisations representing the interests of working women.
\end{abstract}

a n the USA, smoking follows a social class gradient. ${ }^{1}$ For adults, higher smoking rates are associated with lower educational attainment, working class occupations, and lower income levels. For those in working class occupations, the smoking rate in 2000 was $34.6 \%$, compared with $17 \%$ among those in professional or managerial occupations. ${ }^{1}$ Thus, for those working in tobacco control or public health, or both, one key to reducing class based inequalities in smoking prevalence that exist among both women and men is to form productive political and programmatic partnerships with organisations that represent and reach the working class. One such channel is organised labour.

But tobacco control advocates and unions have not always worked together on policy issues. In fact, on two tobacco control measures we know to be among the most effectiveexcise tax increases and indoor smoking restrictions ${ }^{2}$ - many unions have backed tobacco industry positions, opposing excise tax increases and legislatively mandated worksite smoking restrictions. This was the case for many unions in the 1980s and 1990s and persists in some regions of the country and some unions. ${ }^{3}$

The tobacco industry, working through its trade association, the Tobacco Institute (TI), developed and nurtured ties to organised labour in the 1980s and 1990s. As part of this effort, the TI engaged with the Coalition of Labor Union Women (CLUW), founded in 1974, to address issues of concern to unionised working women. Between 1988 and 1996, the TI gave CLUW at least \$221 500 to support various CLUW projects, some directly related to tobacco policy (excise taxes and worksite smoking restrictions) and others not (organising and membership drives). Nationally, CLUW supported the tobacco industry's political positions on excise taxes and worksite smoking restrictions. ${ }^{3}$

We have two goals in writing this paper: (1) to assess how the tobacco industry established a political relationship with CLUW and used this relationship to oppose smokefree worksite policies and increases in the tobacco tax, and (2) to learn from this example how advocates of strong tobacco control policies can work more effectively with CLUW and other organisations with which working women are affiliated.

\section{THEORETICAL FRAMEWORK}

Within political arenas, policy success is often determined by the right confluence of ideas, institutions, and interests. "Institutions" are the enduring rules, procedures, and organisations under and through which the relevant policymakers and other parties interact and conduct their business. "Interests" refer to the constellation of economic, social, political, or other groupings of people whose preferences are probably taken into account by policymakers. "Ideas" include citizens', stakeholders', and policymakers' understandings of a problem and the solutions to that problem. ${ }^{3}$

While the tobacco industry has a clearly recognised interest in legislation favourable to its economic health, and backs that interest with substantial campaign contributions, its policy success also relies on its ability to use ideas to attract other interest groups into mutually beneficial coalitions. Such coalitions provide an institutional mechanism for the tobacco industry to press its political agenda in a less obvious way. For example, in 1989, one of the TI's methods for opposing excise tax increases was "to shift the focus from the product to the individual paying the tax." ${ }^{15}$ This meant that they wanted less focus on the dangers of smoking, which justifies tax increases as a pathway to reduce smoking, and more on the unfairness of increasing the tax burden on the smoker. The TI used its relationship with CLUW to highlight the regressive nature of excise taxes and their impact on working women.

Another example of how the TI used a combination of ideas, interests, and institutions is the issue of smokefree worksites. The tobacco industry sought to form coalitions, an important political institution, with key interest groups like CLUW and other labour groups by framing its ideas in a way that would appeal them. According to Susan Stuntz, a vice president of the TI,

Abbreviations: TI, Tobacco Institute; CLUW, Coalition of Labor Union Women; LMC, Labor Management Committee; TDO, Tobacco Documents Online; UCSF, University of California at San FRancisco 
"In order to generate labor support for the public smoking issue ... we had to redefine it. In this case ... we emphasized first collective bargaining and ... later... indoor air quality... When we frame it in this context, the labor interest expands beyond collective bargaining to worker health and safety and new jobs. ${ }^{16}$

If the industry had tried to frame either worksite smoking policies or excise tax increases in pro-labour ways, without involving unions, its arguments probably would have been perceived as self serving. Organised labour, on the other hand, could potentially argue the industry's case from a liberal/labour perspective. Organised labour will sometimes oppose worksite smoking policies because of its position that management is responsible for maintaining a healthy and safe work environment. If management's only effort in this regard is to implement smokefree worksite rules, without dealing with other worksite hazards, then organised labour may not support smokefree worksite policies. Similarly, organised labour may object to management changing work rules without collective bargaining.

Using either of these frames, the imposition of worksite smoking restrictions becomes a legitimate worker issue. If the TI tried on its own to argue that smoking is just one cause of poor quality air in the work environment, it might have struggled. Similarly, if the industry opposed excise taxes because they are regressive and place most of the burden on low income groups among whom smoking prevalence is highest, and advocated that all taxpayers should help to fund universal health care, not just smokers, their argument would have been less credible. Thus, the tobacco industry had an incentive to pursue a relationship with organised labour.

This paper will examine how the tobacco industry, working primarily through the TI and its Tobacco Industry Labor Management Committee (LMC) was able to use ideas, especially issue framing, and money to build a relationship with the CLUW. With CLUW and other elements of organised labour engaged as interested parties supporting TI political positions, political institutions sympathetic to organised labour, such as democrats and liberals, were more likely to support TI positions as well. Our goal is to help public health advocates think through how they might also be able to use a similar strategy to build relationships with organisations that represent working class women, including organised labour.

\section{METHODS}

As a result of the Master Settlement Agreement, over 40 million pages of tobacco industry internal documents produced in the course of litigation are available on line through the Legacy Tobacco Documents Library at the University of California at San Francisco (UCSF) (http:// legacy.library.ucsf.edu) and through Tobacco Documents Online (TDO) (http://tobaccodocuments.org). From our previous work on the $\mathrm{LMC}^{3}$ and on industry targeting of working class women, ${ }^{1}$ we had a core set of 800 documents related to working class women, CLUW and CLUW's relationship with the LMC.

To make sure that we had as complete a set as possible of key documents, we then searched under both "CLUW" and "Coalition of Labor Union Women" as keywords in both the UCSF Legacy and TDO databases. At TDO, there are two TI collections. The first is indexed and was released in 1998, along with the documents from the major tobacco companies. This collection is also available at the UCSF/Legacy site. The second collection is not indexed and can only be searched using full text searching. Full text searching is sometimes unreliable because the documents have been electronically scanned, which does not always work well on poor quality originals. This second collection became available when the
Master Settlement Agreement dissolved the TI and represents the institute's complete files. While not all files have yet been made available for searching, they are a valuable resource, and we also searched these files for mention of CLUW or the Coalition of Labor Union Women. In total, we retrieved 1041 documents.

We did a preliminary sort of all documents found, based on whether they contained a mention of CLUW that was nontrivial. A "trivial" mention would, for example, be if CLUW appeared in a list of organisations that a particular TI consultant had called that month. A "non-trivial" mention included information on meetings with CLUW, financial or other kinds of support, or statements by CLUW. We eventually gathered a dataset of 75 documents that form the basis for this paper.

Once the complete set of non-trivial CLUW documents was retrieved, we filed them in chronological order and constructed a timeline of key events. Two of us (EDB and AH) read all major documents to look for the kinds of interactions that characterised the relationship between CLUW and the TI or LMC. All relevant quotes were extracted into a preliminary findings memo. Because this research was a case study on the relationship between CLUW and the TI, the chronological ordering made sense as an organisational technique.

To triangulate our findings, we looked to two key outside sources: the labour press and academic writing on women in the labour movement. The CLUW News, the in-house newspaper of CLUW, is housed at the Littauer Library at Harvard University. We searched the back issues of the CLUW News (1984-1999) for any mention of smoking, tobacco taxes, or smokefree worksite legislation. We conducted a literature review for other published materials on union women and on CLUW. Silke Roth's book on the formation and operation of CLUW was particularly valuable. ${ }^{7}$

\section{RESULTS}

\section{The LMC}

In the 1980's the TI, the trade association for major tobacco manufacturers in the USA, had identified two policy issues that were likely to threaten the industry in the near future. One was excise tax increases and the other was indoor smoking restrictions. ${ }^{6}$ The industry, as it turns out, was quite right to be apprehensive about these two types of policy initiatives. In a recent meta-analysis of the relative efficacy of different types of interventions, excise taxes and indoor smoking restrictions were shown to have had the greatest positive impacts on reducing smoking rates. ${ }^{2}$

To improve its ability to contest excise tax increases and smokefree worksite policies, in 1984, the TI worked with the Bakery, Confectionery, and Tobacco Workers Unions to establish a LMC. In a 29 May 1987 memo to the TI's Executive Committee, Samuel Chilcote, TI President, summarised the LMC's functions:

(1) Lobbying and briefing elected officials at all levels of government. The majority has been at the federal level.

(2) Discouraging liberal and labour coalitions from taking antitobacco positions.

(3) Building support for industry positions throughout the labour movement.

(4) General public communication. ${ }^{8}$

But the LMC had a limited membership, consisting of those unions representing people who work in the tobacco industry (Bakery, Confectionery, and Tobacco Workers, the Machinists, the Sheet Metal Workers, Firemen and Oilers, and Carpenters and Joiners). The LMC unions were clearly interested in the financial health of the tobacco industry, because they relied upon it for jobs. Thus, the TI needed 
partners who were less obviously self interested to help lobby industry issues. To increase the effectiveness of the LMC in reaching other unions, including their locals, the TI hired a battery of consultants and supported other kinds of outreach efforts. $^{3}$

One group the TI wanted to reach was labour union women. As of the late 1970s, all of the LMC unions were probably predominantly male. In a US Department of Labor survey of union membership conducted in the late 1970s, BC\&T was $74 \%$ male, the Machinists were $87.4 \%$ male, and Carpenters were 98\% male. Although neither the Firemen nor the Sheet Metal Workers reported their data, the Department of Labor indicated that it thought that the Sheet Metal Workers were less than 5\% female and the Firemen slightly above that. ${ }^{10}$ CLUW clearly gave the TI access to a population of working women it could not reach through the LMC unions directly. Furthermore, CLUW's membership had a large number of members drawn from public sector unions, which was a group not represented on the LMC. ${ }^{7}$

\section{The CLUW}

CLUW was established in 1974, when 3200 women union members met and agreed that a coalition of labour union women was needed to serve the interests of unionised women. ${ }^{7}$ Then, as now, CLUW had four goals:

(1) to promote affirmative action in the workplace

(2) to strengthen the role of women within their unions

(3) to organise unorganised women

(4) to increase the involvement of women in the political and legislative process

CLUW was a coalition of trade union members, ${ }^{71}$ designed to be part of and supported by the AFL-CIO unions. ${ }^{7}$ The AFLCIO (which stands for the "American Federation of Labor and Congress of Industrial Organizations") is a federation of trade unions in the USA. Although several unions broke away in 2005, when the LMC was active, the AFL-CIO was the important policy voice for labour at the national level. CLUW's structure was modelled after the AFL-CIO, with an executive council and local affiliates. Eventually, its president sat on the AFL-CIO Executive Council. All of CLUW's national officers were either elected officers or staff members in their own unions and/or received financial support from their unions to attend meetings. ${ }^{7}$ Thus, CLUW was unlikely to strike out in directions not endorsed by their unions or organised labour more generally.

At that first meeting, CLUW decided that only women represented by collective bargaining agreements could be members. This decision stemmed in part from the organisers' fear that a more open organisation would be deflected from working on CLUW's goals. In particular, they worried that elite, non-union, women would try to run an organisation founded to address the concerns of working class women and use it to further a broader feminist agenda. CLUW was interested in being influential within the labour movement, more than the feminist movement. Although it bridged the labour and women's movements, CLUW's primary identity was as a labour organisation. Its focus was on issues of interest to working women, such as reproductive rights, childcare, and sexual harassment, that CLUW's founders thought had been neglected by organised labour. ${ }^{7}$

According to Joyce Miller, the original corresponding secretary who became CLUW's president in 1979, CLUW members did not want to be included in the women's movement as it was defined in the 1970s because of many of the "vague concepts espoused by middle class feminists." ${ }^{11}$ In a 1994 membership survey conducted by CLUW, 52\% of respondents identified themselves as working class and 37\% identified themselves as middle class. ${ }^{7}$

\section{The $\mathrm{TI}^{\prime}$ s interest in CLUW}

Because of the limited number and scope of unions in the LMC, the tobacco industry fairly early began to explore ways to extend the LMC's influence. CLUW was an attractive partner for the tobacco industry, because by 1985, CLUW had 15000 members. $^{7}$ As Ogilvy and Mather, a public relations firm, and James Savarese pointed out in 1989, CLUW, along with the A Philip Randolph Institute (an association of African-American trade unionists) and the Labor Council for Latin American Advancement (an association of Latino trade unionists), could extend the reach of the LMC. According to Ogilvy and Mather,

Each group has deep roots within the labor movement. They are, in essence, coalitions themselves and provide unique access to virtually every segment of the labor movement. As such, they are important vehicles to carry the IAQ [Indoor Air Quality] and excise tax messages to organized labor. ${ }^{12}$

But Ogilvy and Mather and Savarese also recognised the key part that reciprocity played in maintaining coalitions. The memo continues, "It is ... important for the Committee to continue its policy of supporting these organizations in areas unrelated to its agenda. This will continue to strengthen the coalition." 12 The trade off was fairly explicit. According to the September, 1989, Public Affairs Management Progress Report,

The Coalition of Labor Union Women (CLUW), which has agreed to work with us on several excise tax projects including a study, video, and briefings - sought our help with the production of membership recruitment and educational information kits. Where appropriate, excise tax and indoor air quality measures will be inserted in the materials. $^{13}$

As a young organisation, CLUW could be helped in pursuit of its goals by the TI's money. The trade off-opposing excise taxes and wanting all indoor air pollutants, not just smoke, to be dealt with by management-was not difficult to make. These were positions that CLUW might have taken without TI funding. Excise taxes are regressive and were opposed by organised labour at the time. As early as 1980, the AFL-CIO was on record, at the urging of BC\&T, opposing smokefree worksite policies. The EPA finding that secondhand smoke was a class A carcinogen was more than a decade away, and unions were concerned that management, by focusing only on smoking, was shirking its responsibility to protect workers from other toxic substances in the workplace. ${ }^{14}$ Thus, the AFL-CIO position on these issues was clear, and CLUW was part of the AFL-CIO.

\section{Smokefree worksites}

By 1988, the TI was funnelling money to CLUW through the LMC. ${ }^{15}$ During the first two years of the relationship between the LMC and CLUW (1988-1989), IAQ was the focus of the TI's efforts. The first evidence of CLUW involvement with the LMC is in February of 1988 when CLUW president, Joyce Miller agreed to sponsor LMC presentations on IAQ at regional and national conferences that year, including one to over 1200 CLUW members at the fifth biennial CLUW national convention in Seattle, Washington. ${ }^{16}{ }^{17}$ After the presentation, a resolution calling for "enforcement of safe indoor air quality standards in all workplaces" was 
unanimously approved. In addition to the IAQ presentation, there was a national CLUW reception at the conference that the LMC helped make possible. ${ }^{15}$ There were at least three IAQ presentations by LMC representatives to major CLUW audiences between November 1988 and June 1989. ${ }^{16} 17$

During this time, the LMC helped CLUW with media and promotional support at national meetings/conventions and with design, production, and distribution of CLUW membership recruitment materials. The industry's plan was based on reciprocity. If CLUW leadership needed membership brochures and conference support to grow and sustain itself, then the TI could provide that. Sometimes a single publication could serve both purposes.

To expand our reach within this group on $I A Q$, we recommend developing some CLUW-sponsored materials. These materials would be devoted to IAQ and would primarily focus on the health and safety aspects of the issue as they relate to working women.... CLUW stands to gain from these materials because the piece will help the organization in its recruitment efforts. This is an important health and safety issue and CLUW would be seen as out in front on it. At the same time, the Committee would benefit from the increased exposure to the IAQ issue within the working women's network. As CLUW-sponsored documents, they would have important credibility within this network. ${ }^{12}$

In October 1989, an article entitled, "Feeling poorly? Your building may be sick!" appeared in CLUW News, a bimonthly newsletter for CLUW members. This article described "Sick Building Syndrome" and the IAQ presentation given at the previous year's national convention as well as the National Institute for Occupational Safety and Health's (NIOSH) diagnosis of the problem: poor building ventilation. Environmental tobacco smoke was not mentioned. ${ }^{18}$

In the same month, the TI articulated its desire to reach out to labour groups "representing white and pink collar workers by characterizing IAQ as a key office-as opposed to industrial—workplace health issue." 19 This spurred the idea for CLUW "sponsorship" of a monograph on workplace health issues facing women; the TI allocated $\$ 50000$ for the project and prepared an outline of the piece "for discussion with CLUW" by 1989. ${ }^{19} 20$

In 1991, this monograph eventually became a 75 page handbook on workplace hazards entitled, "Is Your Job Making You Sick? A CLUW Handbook on Workplace Hazards." ${ }^{\prime 21}$ This handbook asserted that smoking restrictions were not a solution to the problem of poor IAQ, but were merely an ill fated shortcut that employers might try to take in fixing IAQ problems. Copies of the handbook were sent to all AFL-CIO health and safety officers, CLUW chapter presidents, and union committees on occupational safety and health. ${ }^{22}$

\section{Excise taxes}

The TI was also focused on the excise tax issue, and again sought CLUW's name on a publication. By early in 1990, the TI had plans to present an excise tax programme to CLUW.

Organized labor will continue to be one of our chief allies. We plan to work with them through the Labor Management Committee to support and promote studies examining the impact of excise taxes on their members. In fact, the Coalition of Labor Union Women has already commissioned a study that will demonstrate the effects of regressive taxation on working women. When the work is completed, we will work with them to ensure that the study is placed with key lawmakers and the media. ${ }^{5}$

According to Ogilvy and Mather, Joyce Miller gave preliminary agreement to work with the LMC on presentations on the impact of excise taxes on working women, production of a CLUW tax video, an increase in CLUW sponsored IAQ materials, and submission of articles on LMC issues to CLUW's newsletter. ${ }^{23-25}$ Although these contacts were nominally through the LMC, Susan Stuntz, vice president of the TI, was a key contact. In a 1989 letter, Stuntz comments that their need to discuss the year's plans, "was a wonderful excuse to visit, to enjoy a good restaurant, and to enjoy a good play with friends. Thank you for the opportunity. I have enclosed the Committee's support check for the second half of 1989."'26

By May, 1990, CLUW released a study on federal tax policy and working women entitled, "Women and Children First: An Analysis of Trends in Federal Tax Policy," which included a section on the effects of consumer excise taxes. ${ }^{23}$ The report was released at a press breakfast in conjunction with Working Women's Awareness Week, and was sent to all members of congress and the members of the AFL-CIO executive council. The report was also discussed in the $A F L$ CIO News, a widely distributed labour publication. ${ }^{27}$

The TI, working through Ogilvy and Mather, was heavily involved in the design, drafting, and production of this study. In its May 1990 Activity Report, Ogilvy and Mather reported that it "completed production of Coalition of Labor Union (CLUW) tax study" and also followed the study by drafting op-eds for selected newspapers and coordination of a video news release. ${ }^{28}$ The "op-eds," which were drafted by the TI, were to be submitted to the selected newspapers by Joyce Miller. ${ }^{23}$ As with IAQ programmes, the excise tax issue was presented by LMC representatives at CLUW conventions and meetings throughout the USA.

But the TI again clearly understood the importance of reciprocity. That is, the TI could not just ask CLUW to oppose excise taxes without giving them something legislatively in return, particularly given the number of public employees in CLUW whose jobs depended on tax revenue. According to the TI,

Encouraging groups, particularly those on the left, to speak out against excise taxes is not easy when these organizations favor raising revenue to fund social and jobs programs. Our second strategy to discourage reliance on excise taxes, therefore, is to support these groups in their efforts to demonstrate the viability of progressive alternatives ... For example, we will continue to assist Citizens for Tax Justice with the promotion of its annual examination of "corporate freeloaders" - those corporations that pay no, or little, taxes. ${ }^{5}$

CLUW and the LMC worked together steadily up through the Clinton universal healthcare debate. CLUW was clearly torn, supporting universal health care yet opposed to funding it, as the Clinton administration proposed, with a regressive tax on tobacco products. CLUW instead supported using income and payroll taxes as the "most equitable means of funding health care reform and, therefore, most fair to women, minorities and average working Americans."29

The TI gave CLUW \$10 000 to help fund the "Women's Convergence on Universal Health Care." The conference was likely to support a single payer program, but according to Ogilvy, Adams, and Rinehart (formerly Ogilvy and Mather), "based on our discussions with Joyce, we are certain that a strong progressive financing message can be included in all 
aspects of the conference literature and statements by speakers." ${ }^{\prime 30}$ This would spare the industry from new tobacco excise taxes, which would reduce sales.

\section{CONCLUSION}

To encourage CLUW's opposition to smokefree worksite laws and tax increases the TI provided them with at least \$221 500 between 1988 and 1997. ${ }^{3}$ Although it is difficult to know how much or if the CLUW's involvement in the policy process made a difference, there are indications that organised labour was important in federal level policy making. In the fight over legislation making airplanes smokefree, the flight attendants' unions supported the legislation, which forced the AFL-CIO to remain neutral and the legislation passed. ${ }^{37}$ Stuntz was determined to keep organised labour on its side for subsequent fights. ${ }^{31}$

CLUW endorsed the TI's positions on IAQ and excise taxes, and the TI gave CLUW money for its programmes in return. For example, LMC support to CLUW included development of brochures on various topics such as membership recruitment, empowerment, abortion, etc, a grant for a CLUW reproductive rights project, media and public relations support for CLUW national conferences and meetings, support for receptions at national conventions and meetings, and money for printing of CLUW materials. ${ }^{13}{ }^{15}$ 32-36

But the TI was not asking CLUW to pursue an agenda to which it was opposed. The TI understood that CLUW had serious concerns about how excise taxes and smokefree worksite policies might affect working women and used that understanding to build a political coalition with CLUW. In the 1980s and 1990s, CLUW was concerned about the regressive nature of tobacco tax increases, which CLUW felt

\section{What this paper adds}

- This paper describes how the Tobacco Institute built a relationship with the Coalition of Labor Union Women (CLUW). By framing its issues in a way that would appeal to working women, the institute was able to rely on CLUW to take leadership position opposing excise tax increases and smokefree worksite legislation. The institute's relationship with CLUW has not been described elsewhere.

- By understanding how the institute was able to build a political relationship with CLUW, an organisation founded and trusted by working class women, tobacco control advocates may be better able to understand how they too can work more effectively with organisations that serve working class women.

\section{Policy implications}

For tobacco control advocates to be successful in policy arenas, particularly when trying to pass excise tax increases or smokefree worksite laws, they need to build political coalitions with a wide range of partners. Organised labour can be a key partner. By studying how the tobacco industry built such partnerships, tobacco control advocates may be able to create stronger coalitions and increase their chances of policy success. would have a disproportionate impact on working women, particularly single mothers in low wage jobs. CLUW was also concerned that smokefree worksite laws, if not passed in conjunction with other clean air rules, would leave working women exposed to other worksite toxins. In addition, by accepting money from the TI, CLUW was better able to pursue its organisational goals. Thus, the TI found a way, using issue framing or "ideas", to further its interests by joining them with those of CLUW. The resulting political coalition thus created a new institutional pathway to influence legislation.

Tobacco control advocates may lack the money the TI had to pursue relationships with working class women, but success in politics is not solely reliant on money. Without a strong "ideas" based programme, the TI might not have had the success it did with organised labour. The TI took time to understand how its potential coalition partners viewed issues and how it could frame its issues to match those values. This aligning of interests was key to its success in creating its coalition.

Advocates for effective tobacco control policies, such as smokefree worksites and tax increases, can learn from the industry's example how to use ideas to build similar relationships with organisations representing working class women. Tobacco control advocates can re-frame and broaden their issues so that the concerns of working class women can be addressed more effectively. For example, at the time CLUW and the TI were working together, secondhand smoke had not been declared a class A carcinogen. That did not occur until 1992. In addition, the studies showing that smokefree laws that banned smoking in bars and restaurants do not affect revenues and jobs had not been done. Clearly, these kind of data can be very useful. Smoke, particularly in office settings, bars/restaurants, airplanes, etc, is probably a chief pollutant and tobacco advocates need to build on and use those scientific findings. Such a coalition did form, for example, between flight attendant unions and tobacco control advocates in working for smokefree airplanes. ${ }^{37}$ Such political coalitions can create a stronger institutional presence than individual organisations might have on their own. ${ }^{3}$

In addition, however, tobacco control advocates also need to learn about reciprocity; women at work do face other worksite hazards and it does not diminish the importance of smokefree air to acknowledge that other issues are health issues, too. That is, if two parties want to engage each other's interests in a policy effort, they must be respectful of what each other wants and needs.

Similarly, tobacco control advocates need to understand that, while tobacco tax increases as a tobacco use prevention policy may have positive effects on smoking prevalence, they also do have a disproportionate effect on smokers, who increasingly are working class men and women. While this may not dissuade tobacco control advocates from pursuing such policies, tobacco control advocates should be prepared to acknowledge that smokers should not be the only ones paying for vital social services.

Ideas have a key part to play in forming political coalitions. Such coalitions can be key institutions in achieving successful policy outcomes. But to form such coalitions, potential partners need to understand each other's issues, to frame them in such a way that both interests can support them, and to engage in reciprocal acts to show that support. In planning pathways to reach working class women, tobacco control can learn from observing tobacco industry behaviour. If tobacco control policies are going to have an effect on working class women, then tobacco control advocates need to learn how to deal effectively with the organisations that already serve these women. 


\section{Authors' affiliations}

E D Balbach, A Herzberg, Community Health Program, Tufts University, Medford, USA

E M Barbeau, Dana Farber Cancer Institute and Harvard School of Public Health, Boston, USA

Funding: this research was supported by $\mathrm{NCl}$ grant $\mathrm{RO} 1 \mathrm{CA095964}$.

Conflicts of interest: none declared.

\section{REFERENCES}

1 Barbeau E, Leavy-Sperounis A, Balbach E. Smoking, social class, and gender: What can public health can learn from the tobacco industry about disparities in smoking? Tob Control 2004;13:115-20.

2 Levy D, Chaloupka F, Gitchell J. The effects of tobacco control policies on smoking rates: A tobacco control scorecard. J Public Health Mgmt Prac 2004; 10:338-53.

3 Balbach E, Barbeau E, Manteufel V, et al. Political coalitions for mutual advantage: the case of the tobacco industry's Labor Management Committee. Am J Public Health 2005;95:985-93.

4 Heclo H. Ideas, interests, and institutions. In: Dodd LC, Jillson C, eds. The dynamics of American politics. Boulder, CO: Westview Press, 1994:366-95.

5 Tobacco Institute. Presentation to Communications Committee. Tobacco Documents On-line, 1989:T151541525/1531. (http:// tobaccodocuments.org)

6 Stuntz SM. Labor Presentation to the Communications Committee. Tobacco Documents On-line, New York Archives, 1988:TCAL0060863/0931. (http:// tobaccodocuments.org).

7 Roth S. Building movement bridges: the coalition of Labor Union Women. Westport, CT: Praeger, 2003.

8 Chilcote S. Memorandum. UCSF Legacy Library, 1987;TI DN 0002799/ 2803. (http://legacy.library.ucsf.edu)

9 Bureau of Labor Statistics US Department of Labor. Directory of National Unions and Employee Associations. Washington, DC, 1975:24-45, 103-4.

10 Bureau of Labor Statistics US Department of Labor. Directory of National Unions and Employee Associations. Washington, DC: 1977, 24-45, 100-1.

11 Cobble DS. The other women's movement: workplace justice and social rights in modern America. Princeton, NJ: Princeton University Press, 2004

12 Ogilvy and Mather, Savarese and Associates. LCLAA, CLUW, APRI/IAQ, Excise Taxes. New York State Archive, 1989:TCAL0057396/7399. (http:// legacy.library.ucsf.edu).

13 Schoonmaker D. Public Affairs Management Plan Progess Report September 1989. UCSF Legacy Library, 1989;TIDN0016977/7014. (http:// legacy.library.ucsf.edu)

14 AFL-CIO policy rejects anti-smoking campaigns. BC\&T News 1980;1

15 Dawson L. CLUW Convention - November 17-20. In: TNWL0045899. UCSF Legacy Library, 1988;TNWL0045899. (http://legacy.library.ucsf.edu).

16 Tobacco Institute. Communication Efforts November 1988. UCSF Legacy Library, 1988;TI01262201/04. (http://legacy.library.ucsf.edu)
17 Tobacco Institute. Communications Efforts March 1989. UCSF Legacy Library, 1989; TI01262183/2186. (http://legacy.library.ucsf.edu).

18 Tobacco Institute. Feeling poorly? Your building may be sick! TIOK0011399. UCSF Legacy Library, 1989;TIOK0011399. (http://legacy.library.ucsf.edu).

19 Tobacco Institute. Public smoking programs of the Tobacco Institute. UCSF Legacy Library, 1989;2025861092/1 101. (http://legacy.library.ucsf.edu).

20 Tobacco Institute. 1990 (900000) Budget. UCSF Legacy Library, 1989;508122005/2068. (http://legacy.library.ucsf.edu)

21 Coalition of Labor Union Women. Is your job making you sick? A CLUW handbook on workplace hazards. UCSF Legacy Library, $1991 ; 2045942306 / 2381$. (hitp://legacy.library.ucsf.edu)

22 Chilcote SD. Report on the Coalition of Labor Union Women's (CLUW) new handbook on workplace aazards, which includes discussion of indoors air quality issues. UCSF Legacy Library, 1991;TI16792126. (http:// legacy.library.ucsf.edu)

23 Chilcote SD. Tobacco Institute. UCSF Legacy Library, 1990;93801406/1412. (http://legacy.library.ucsf.edu)

24 Miller J. The Tax Picture Women. TIMN0343322. UCSF Legacy Library, 1990;TIMN0343322. (http://legacy.library.ucsf.edu).

25 Tobacco Institute. Allies: Summary of Activities. Tobacco Documents Online, 1991:T151280673/0679. (http://tobaccodocuments.org).

26 Stuntz SM. Letter to Joyce Miller. , Tobacco Documents Online, 1989:TI17682251. 1991:TI51280673/0679. (http:// tobaccodocuments.org).

27 Tobacco Institute. Excise Tax Issue. Tobacco Documents Online, 1990:TI51 150792. 1991:TI51280673/0679. (http:// tobaccodocuments.orgl.

28 Moeller J. May Activity Report. Tobacco Documents Online, 1990:T109651957. 1991:T151280673/0679. (http:// tobaccodocuments.org)

29 Dratch G. Coalition of Labor Union Women National Executive Board Meeting. Tobacco Documents Online, 1993:TCAL0158383/8385. 1991:T151280673/0679. (http://tobaccodocuments.org).

30 Dawson L, Dratch G, Shulman E. CLUW Health Care Conference. Tobacco Documents On-Line, 1993:T151282372/2374. 1991:TI51280673/0679. (http://tobaccodocuments.org).

31 Stuntz SM. Remarks to the Executive Committee. In: New York State Archives, 1989, TI1 1871026/1076

32 Savarese J. Labor Management Committee March Activity Report. UCSF Legacy Library, 1993:TI01480788. (http://legacy.library.ucsf.edu).

33 Tobacco Institute. Check Request. Tobacco Documents Online, 1993:TI51282377. (http://tobaccodocuments.org).

34 Rinker M, Ransome S, Fernicole K. Public Affairs Management Progress Report. Tobacco Documents Online, 1991:T152201478/1515. (http:// tobaccodocuments.org)

35 Tobacco Institute. Allies Summary of Activities. TI51280673/0679. Tobacco Documents Online, 1991. (http://tobaccodocuments.org).

36 Moeller J. Labor Management Committee May Activity Report. UCSF Legacy Library, 1992:TIMN0388159/8160. (http://legacy.library.ucsf.edu).

37 Pan J, Barbeau E, Levenstein C, et al. Smokefree airlines and the role of organized labor: a case study. Am J Public Health 2005;95:398-404. 